\title{
Ownership structure, horizontal agency costs and the performance of high-tech entrepreneurial firms
}

\author{
Massimo G. Colombo • Annalisa Croce • \\ Samuele Murtinu
}

Accepted: 23 March 2013/Published online: 11 April 2013

\begin{abstract}
We use the lens of the resource-based view and horizontal agency cost theory to analyse the effect of the presence of different types of individual owners, i.e., owner-managers and non-manager individual shareholders, on the performance of high-tech entrepreneurial firms. Ownership enlargement may contribute to fill the resource gap faced by entrepreneurial firms and improve firm performance. However, whereas owner-managers engender low horizontal agency costs, non-manager individual shareholders generate high horizontal agency problems because of their limited managerial involvement. Our results on a sample of Italian high-tech entrepreneurial firms show that the number of owner-managers has a positive effect on firm performance, whereas the effect of the number of non-manager individual shareholders is negligible. This latter effect becomes more positive, even though still not statistically significant, when firms are highly leveraged confirming the disciplining role of bank debt.
\end{abstract}

Keywords Horizontal agency costs · High-tech entrepreneurial firms · Productivity · Ownership structure $\cdot$ Bank debt

M. G. Colombo · A. Croce $(\bowtie) \cdot$ S. Murtinu Department of Management, Economics and Industrial Engineering, Politecnico di Milano, Via R. Lambruschini, 4/b, 20156 Milan, Italy

e-mail: annalisa.croce@polimi.it

\section{Introduction}

High-tech entrepreneurial firms are a key driver in increasing the dynamic efficiency of economic systems (Acs and Audretsch 2003; Audretsch 1995) and creating new jobs (Autio and Parhankangas 1998). ${ }^{1}$ However, the extant literature argues that high-tech entrepreneurial firms suffer from financial constraints (Bertoni et al. 2010; Carpenter and Petersen 2002a) and lack commercial and managerial competences (Gans and Stern 2003; Teece 1986) that hinder their growth and threaten their survival (Carpenter and Petersen 2002b).

These gaps in financial and non-financial resources ${ }^{2}$ may be addressed through changes in a firm's ownership structure. From a resource-based perspective, ownership enlargement positively affects firm performance through the firm's newfound access to financial

In Europe, small and medium enterprises account for more than $67 \%$ of jobs in the private sector (87.5 million in 2010) and more than $58 \%$ of total turnover (European Commission 2011).

${ }^{2}$ Many works referred to these gaps as the 'funding' gap and 'knowledge' gap, respectively (e.g., Colombo and Grilli 2005; Storey and Tether 1998; Van Auken 2001). 
and/or non-financial resources and competences. The drawback of this change in ownership structure is that agency costs may arise and these latter have negative effects on firm performance. In entrepreneurial firms, the primary agency problem is the so-called 'principal-principal' (PP) conflict, which gives rise to 'horizontal' agency costs (Young et al. 2008). Horizontal agency costs are related to the fact that different principals have heterogeneous interests, preferences and objec-tives (Connelly et al. 2010; Walsh and Seward 1990; Ward and Filatotchev 2010). Dalziel et al. (2011: p. 1349) claim that there is significant potential for interest heterogeneity to incite conflict among princi-pals' due to differences in risk preferences, preferred investment holding periods and so on.

In this article, we argue that the extent of both the benefits arising from ownership enlargement and the horizontal agency costs depend on the role played by different (individual) owners. To improve the endowment of resources and competencies, entrepreneurial firms may enlarge their team of owner-managers and/ or open up their ownership to non-manager individual shareholders. We define an 'owner-manager' as an individual owner who is actively involved in the firm's management and typically plays the role of chief executive officer (CEO), chief technical officer (CTO), chief financial officer (CFO) or chief marketing officer (CMO). A 'non-manager individual shareholder' is defined as an individual owner who provides capital to the focal entrepreneurial firm, but is not involved in firm's management, i.e., she/he does not have any managerial responsibility. Because of the involvement in the firm's daily operations, an ownermanager can effectively monitor the actions of the other owner-managers. Conversely, non-manager individual shareholders are likely to generate agency problems. Due to the absence of managerial involvement, non-manager individual shareholders have a more limited information set about firm's managerial decisions than that possessed by owner-managers (Dalziel et al. 2011). Therefore, whereas a larger number of owner-managers is likely to positively contribute to firm performance, it is questionable whether the presence of non-manager individual shareholders does.

Moreover, we examine whether financial debt reduces the horizontal agency costs related to the presence of non-manager individual shareholders. On the one hand, the threat of bankruptcy, which increases with firm's leverage, acts as an effective motivating force and makes the behaviour of owner-managers less opportunistic. On the other hand, banks' incentive to monitor owner-managers' actions is directly related to the firm's default risk. Therefore, we expect that a firm's debt exposure contributes to reduce horizontal agency costs, leading to a more beneficial impact of non-manager individual shareholders on firm performance.

Our work contributes to the literature on the relationship between ownership structure and entrepreneurial firms' performance. To the best of our knowledge, this is the first attempt to study the impact of different types of individual owners (i.e., ownermanagers and non-manager individual shareholders) on firm performance. Moreover, this is the first empirical study that combines arguments from the resource-based view and horizontal agency cost theory to understand the relationship between ownership structure and high-tech entrepreneurial firms' performance. $^{3}$

In the empirical part of the article, we consider an unbalanced panel data set composed of 255 Italian unlisted high-tech entrepreneurial firms observed from 1994 (or since their foundation) to 2003. We measure firm performance through total factor productivity (TFP) growth. TFP is a classical indicator of firm efficiency ${ }^{4}$ that is attracting increasing interest from entrepreneurship scholars (see Colombo et al. 2009 for a detailed illustration of this literature). We estimate TFP through the semi-parametric approach proposed by Olley and Pakes (1996). We assess the impact of ownership structure on TFP growth through a system GMM (generalised method of moments) estimator for panel data to control for unobserved heterogeneity, feedback effects and measurement errors (Blundell and Bond 1998).

\footnotetext{
3 This work is not the first attempt to combine arguments from the resource-based view and agency cost theory (e.g., Hillman and Dalziel 2003). However, it is the first study that does so in the field of high-tech entrepreneurship. In this effort, we follow the suggestions provided by Barney et al. (2001).

${ }^{4}$ The use of an efficiency indicator to measure agency costs is suggested by Ang et al. (2000). In their paper, they use a quite unsophisticated efficiency indicator: the ratio between annual sales and total assets. This measure has subsequently been employed by Singh and Davidson (2004). With regard to horizontal agency costs, Dalziel et al. (2011) claim that principal-principal conflicts lead to inefficiencies at the firm level, thus confirming our choice.
} 
The article proceeds as follows. In the next section, we briefly synthesise the extant literature and derive our research hypotheses. In Sect. 3, we describe the data set. In Sect. 4, we describe the performance measure we employ (Sect. 4.1), the econometric specification we use to study the relationship between ownership structure and firm performance (Sect. 4.2), the estimation method to which we resort to control for the endogenous nature of the above-mentioned rela-tionship (Sect. 4.3), and the test we apply to control for the potential presence of survivorship bias in our data (Sect. 4.4). In Sect. 5, we illustrate the results of the econometric estimates. Finally, a discussion of the main findings and their implications in Sect. 6 concludes the article.

\section{Theoretical background and research hypotheses}

According to the resource-based view, a firm's bundle of resources and competencies determines firm performance (e.g., Barney 1991; Barney et al. 2001). At foundation, high-tech entrepreneurial firms allegedly possess innovative ideas for new products, processes or services, but often do not possess all the necessary resources and competencies for the commercial exploitation of such ideas (Gans and Stern 2003; Teece 1986). On the one hand, initial competences of high-tech entrepreneurial firms largely coincide with the skills and knowledge of founders (Colombo and Grilli 2005; He 2008). Founders usually exhibit sophisticated technical skills but lack commercial and managerial competencies to understand users' requirements and assure the efficiency of operations. On the other hand, previous studies have argued that high-tech entrepreneurial firms are likely to be financially constrained (Bertoni et al. 2010; Carpenter and Petersen 2002a; Colombo and Grilli 2007). They suffer from high information asymmetries in capital markets because of (1) the technology-intensive nature of their activity; (2) their lack of a track record; and (3) their predominantly intangible assets (e.g., founders' human capital), which cannot be used as collateral in bargaining with financial institutions.

Both knowledge and funding gaps can be filled through changes in a firm's ownership structure. Indeed, ownership enlargement positively affects firm performance through the access to additional financial and/or non-financial resources and competences. However, the presence of several owners may engender agency costs that are detrimental to firm performance. Different owners (referred to as 'principals' by Young et al. 2008 and Dalziel et al. 2011) do not necessarily have common interests. On the contrary, they may diverge in their preferences, goals and perceptions on risks and returns associated with different corporate strategies.

The horizontal agency costs arising from these discrepancies are low when all owners are actively involved in their firm's management and can easily monitor each other's actions. However, even in this situation, the enlargement of the owner-managers' team may generate free-riding problems in monitoring activities (Aghion and Tirole 1997) and increase the coordination costs incurred in firm's decision-making processes (Kahneman et al. 1982). Even though these arguments speak in favour of an inverse U-shaped relation between the number of owner-managers and firm performance, in high-tech entrepreneurial firms the size of the owner-managers' team is generally small. As will be documented in Sect. 3, in our sample the median number of owner-managers is two and only $25 \%(10 \%)$ of sample firms have more than three (5) owner-managers. Hence, it is reasonable to assume that high-tech entrepreneurial firms are usually in the increasing part of the inverse U-shaped relationship. We therefore derive hypothesis $\mathrm{H} 1$ :

H1 The number of owner-managers positively influences firm performance.

Conversely, if a portion of a firm's equity is owned by non-manager individual shareholders, horizontal agency costs are likely to be high. In this situation, owner-managers have room to engage in actions that diverge from those aimed at maximising firm profits (Chang 2003) and provide them with private benefits to the detriment of non-manager individual shareholders. ${ }^{5}$ These latter, being 'outsiders', do not have resources and expertise to monitor the day-to-day

\footnotetext{
5 For instance, owner-managers may collude and engage in actions that maximise their personal utility but negatively affect firm performance, e.g. by placing unqualified relatives or friends in managerial positions (Faccio et al. 2001) or by purchasing materials for private benefits (Chang and Hong 2000).
} 
activities of the firm in which they have an equity stake, thus resulting in ineffective monitoring (Ang et al. 2000). On the basis of the above-mentioned arguments, the presence of non-manager individual shareholders in an entrepreneurial firm's equity is expected to have two opposite effects on firm performance: (1) a positive effect from the additional resources provided to the focal entrepreneurial venture and (2) a negative effect from the presence of horizontal agency costs. As a result, if these two forces are balanced, we expect that the number of nonmanager individual shareholders has a negligible effect on firm performance.

Hypothesis $\mathrm{H} 2$ follows:

H2 The number of non-manager individual shareholders does not significantly influence firm performance.

However, the extent of the above-mentioned horizontal agency costs is influenced by the existence of external disciplining devices. In particular, in this work we analyse the potentially beneficial effect of leverage in reducing horizontal agency costs. As highlighted by Williamson (1988), debt is not only a 'financial instrument', but also a 'governance structure'. When leverage is high, banks have strong incentives to closely monitor a firm's activities (Harvey et al. 2004). As indicated by Ang et al.(2000, p. 82), 'heavy reliance of the non-publicly traded firms on bank financing could give banks a special role in delegated monitoring on behalf of other shareholders'. Banks require firms' owner-managers to report results honestly and run their business efficiently. Moreover, bank monitoring encourages leveraged firms to use their assets more efficiently and discourages perquisite consumption, producing posi-tive effects on firms' performance. In addition, when leverage is high, the threats of bankruptcy and/or violation of debt covenants act as effective motivating forces in making the behaviour of owner-managers less opportunistic, and firms more efficient (Shleifer and Vishny 1997). This argument is in line with Jensen's (1986) contention that financial debt can be used to motivate firms' top managers to make an efficient use of free cash flows. We therefore expect that, when a firm is highly leveraged, the horizontal agency costs engendered by the presence of non-manager individual shareholders are reduced. This way, the net contribution of the number of non-manager individual shareholders to firm performance should be more positive. We thus derive hypothesis H3:

H3 The effect of the number of non-manager individual shareholders on firm performance is positively influenced by firm's leverage.

\section{Data}

In this article, we use a sample of 255 Italian high-tech entrepreneurial firms that were observed from 1994 (or from their foundation, if it occurred after 1994) to 2003. Sample firms were established in 1980 or later, were independent at foundation date and remained so up to 1 January 2004 (i.e., they were not controlled by another business organisation although other organisations may have held minority shareholdings). They operated in the following high-tech industries in manufacturing and services: computers, electronic components, telecommunication equipment, optical, medical and electronic instruments, biotechnology, pharmaceuticals, advanced materials, avionics, robotics and process automation equipment, multimedia content, software, Internet services and telecommunication services. All of the sample firms are privately held.

The sample is drawn from the RITA (Research on Entrepreneurship in Advanced Technologies) data set, developed at Politecnico di Milano. The RITA data set provides information on 1,974 Italian entrepreneurial firms that comply with the above-mentioned criteria relating to age, ownership and industry of operations. For the construction of the RITA population of firms a number of sources were used. These included lists provided by national industry associations, on-line and off-line commercial firm directories, and lists of participants in industry trades and expositions. Information provided by the national financial press, specialised magazines, other industry studies and regional Chambers of Commerce was also considered. Unfortunately, data provided by the official national statistics do not allow obtaining a reliable description of the universe of Italian entrepreneurial firms. In the absence of official statistics on Italian high-tech entrepreneurial firms, the RITA data set is the most detailed and comprehensive source of data on this type of firms. The data included in the RITA data set originate from two sources. The first source is a series 
of surveys administrated in the first halves of 2000 , 2002 and 2004 and sent to the firms included in the RITA population. Data collected through these surveys include individual owners' identity, the entry year of individual owners into their firm's equity and their role within the firm, and the geographic area and industry in which the firm operates. Data on ownermanagers and non-manager individual shareholders were cross-checked with secondary sources, in particular with the official Register of Companies, which represents the most reliable official source with the full backing of legal guarantees. The second data source includes secondary sources from which we obtained financial and accounting data (i.e., the AIDA and CERVED commercial databases), which are available from 1994.

The RITA data set has several strengths. First, it is not affected by the selection bias found in samples exclusively composed of IPO firms (e.g., Dalziel et al. 2011; Filatotchev et al. 2006). Second, data on sample firms are very informative and allow us to build a rich set of instruments for variables relating to different types of owners that can be used in the econometric estimation. Third, the RITA data set does not include lifestyle firms and firms that are created purely for taxsaving objectives because of the procedure that was used to build the RITA population of firms. ${ }^{6}$

A potentially serious problem in our data set that is common to all survey-based studies (for an exception, see Eckhardt et al. 2006) is survivorship bias. Namely, only firms having survived up to the survey date could be included in the sample. In principle, attrition may generate a sample selection bias in our estimates. The failure rates of firms are likely to decrease with the access to the resources and competences provided by owner. To the extent that among firms with a small number of owners, only the best performers are likely to be observed, the impact of the number of owners on firm performance might be higher than the one highlighted by our empirical analysis. We implement a partial control for this selection bias (described in Sect. 4.4) that suggests that our results are not affected by survivorship bias.

\footnotetext{
${ }^{6}$ In Italy, most individuals who are defined as self-employed by official statistics (i.e., 'independent employees') are in fact salaried workers with atypical employment contracts. This makes the official number of high-tech entrepreneurial firms in Italy enormously inflated.
}

The distribution of sample firms across industries, geographic areas and foundation dates is illustrated in Table $1 .^{7} \mathrm{~A}$ higher number of sample firms operate in services $(61.96 \%)$ than in manufacturing industries. Moreover, sample firms are often located in the northwestern part of Italy $(49.80 \%)$. The $\chi^{2}$ tests show that there are no statistically significant differences between the distribution of the 255 sample firms across geographic areas and the corresponding distribution of the RITA population from which the sample was drawn $\left(\chi^{2}(3)=5.63\right)$. Conversely, sample firms are somewhat older than the population $\left(\chi^{2}(3)=\right.$ 60.13), with the foundation date being more (less) concentrated in 1992-1997 (1998-2003). The reason for this is probably that: (1) in Italy, all limited liability companies are obliged by law to publish yearly accounting data, whereas publication is not mandatory for other firms; (2) the limited liability status is less common among very young high-tech entrepreneurial firms. It is worth noting that very young firms provide limited insights in our analysis because it is necessary to observe firms over several years to assess the effects of ownership structure on productivity growth. Finally, sample firms are more (less) concentrated in the software (web-services) industry $\left(\chi^{2}(2)=9.51\right)$.

\section{Methodology}

\subsection{Performance measure}

We employ total factor productivity (TFP) growth as a measure of firm performance. Previous studies claim that horizontal agency costs are a potential source of inefficiency (Dalziel et al. 2011). Therefore, it is natural to employ a measure of firm efficiency, such as TFP, to assess the extent of these costs as a function of a firm's ownership structure. Obviously, agency costs are inversely related to firm efficiency. ${ }^{8}$ TFP reflects how effectively the focal entrepreneurial firm uses

\footnotetext{
7 We aggregate RITA industries into three macro industries: manufacturing, software and web services. We do so because we need a sufficient number of observations in each industry to estimate TFP (see Sect. 4.1).

${ }^{8}$ It is worth noting that we may underestimate total (horizontal) agency costs, as firm efficiency does not fully capture indirect agency costs, such as: (1) potential distortions in operating and strategic decisions due to agency problems and (2) agency costs not included in financial statements, such as the private
} 
Table 1 Distribution of sample firms across industries, geographic areas and foundation dates

\begin{tabular}{lrr}
\hline & No. of firms & $\%$ \\
\hline Industry & & \\
Web services & 70 & 27.45 \\
Software & 88 & 34.51 \\
Manufacturing & 97 & 38.04 \\
Total & 255 & 100.00 \\
Geographic area & & \\
Northwest & 127 & 49.80 \\
Northeast & 57 & 22.35 \\
Centre & 40 & 15.69 \\
South \& Isles & 31 & 12.16 \\
Total & 255 & 100.00 \\
Foundation period & & \\
1980-1985 & 43 & 16.86 \\
1986-1991 & 60 & 23.53 \\
1992-1997 & 101 & 39.61 \\
1998-2003 & 51 & 20.00 \\
Total & 255 & 100.00 \\
\hline
\end{tabular}

Web services includes Internet service providers, web consulting services, e-commerce and electronic publishing. Manufacturing includes biotechnology and pharmaceuticals, electronic components, telecommunication equipment, computers, electronic, optical and medical equipment, and automation equipment and robotics

production inputs to produce output with respect to the production function estimated for each industry. As explained by Colombo et al. (2009), an increase in TFP is the result of an 'output-side' effect (i.e., the customer's higher willingness to pay, or higher market coverage) and/or an 'input side' effect (i.e., a more efficient use of production inputs). Whatever the source, a TFP increase documents an increase in the firm's overall economic performance.

In accordance with the above-mentioned arguments, the use of TFP as an indicator of high-tech entrepreneurial firms' efficiency is well established in the entrepreneurship, economics and finance literature. There are many examples of applications with samples partially or totally constituted by high-tech firms (e.g., Aghion et al. 2009; Driffield et al. 2008; Hall and Mairesse 1995; Javorcik 2004) and young or

Footnote 8 continued

monitoring costs incurred by non-manager individual shareholders (for more details, see Ang et al. 2000). small firms (e.g., Aitken and Harrison 1999; Chemmanur et al. 2011; Cingano and Schivardi 2004; Colombo et al. 2009; Croce et al. 2012).

We use accounting data to build our indicator of firm efficiency. As firm output, we use the logarithm of sales. As firm inputs, we use the logarithm of fixed assets (i.e., the sum of tangible and intangible assets) and the logarithm of payroll expenses. We then measure TFP levels for each firm in each year as the residuals of the production function estimated through the semi-parametric approach proposed by Olley and Pakes (1996) by industry. ${ }^{9}$

Figure 1 reports the median value of firm TFP contingent on the number of owner-managers and non-manager individual shareholders. As preliminary evi-dence, it is interesting to observe that firm TFP appears to increase with the number of ownermanagers. Conversely, there is no clear relationship with the number of non-manager individual shareholders.

\subsection{Econometric specification}

To test our research hypotheses, we resort to the following dynamic model:

TFP_Growth ${ }_{i, t}=\gamma \mathrm{TFP}_{i, t-1}+\beta_{1} \mathrm{OM}_{i, t}+\beta_{2} \mathrm{NMS}_{i, t}$

$$
+\delta_{j} Z_{i, t}^{j}+\varepsilon_{i, t},
$$

where TFP_Growth ${ }_{i, t}$ is the growth of the TFP of firm $i$ between time $t-1$ and $t, \operatorname{TFP}_{i, t-1}$ is the level of the TFP of firm $i$ at time $t-1, \mathrm{OM}_{i, t}$ is the number of owner-managers of firm $i$ at time $t$; $\mathrm{NMS}_{i, t}$ is the number of non-manager individual shareholders of firm $i$ at time $t$; and $Z_{i, t}^{j}$ are control variables. Finally, $\varepsilon_{i, t}$ is the usual independent identically distributed (i.i.d.) error term. Given that $\mathrm{TFP}_{i, t}$ is measured as the residual of a firm-level production function in which output and inputs are expressed in logarithms (as described in Sect. 4.1), TFP_Growth ${ }_{i, t}$ can be proxied as

TFP_Growth ${ }_{i, t}=\mathrm{TFP}_{i, t}-\mathrm{TFP}_{i, t-1}$.

By substituting (2) in (1), we obtain the following baseline econometric model (model I):

\footnotetext{
${ }^{9}$ For more details on the estimation of TFP and on the choice of output and input variables, see Van Biesebroeck (2007) and Levinsohn and Petrin (2003).
} 


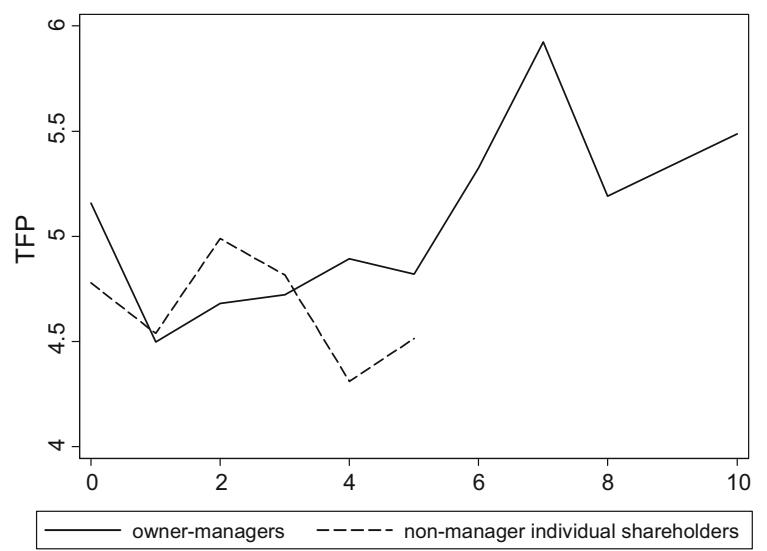

Fig. 1 TFP and ownership structure

$$
\begin{aligned}
\mathrm{TFP}_{i, t}= & \alpha \mathrm{TFP}_{i, t-1}+\beta_{1} \mathrm{OM}_{i, t}+\beta_{2} \mathrm{NMS}_{i, t} \\
& +\delta_{j} Z_{i, t}^{j}+\varepsilon_{i, t},
\end{aligned}
$$

where $\alpha$ is equal to $(1+\gamma)$, with $\gamma$ representing the impact of the lagged value of TFP on TFP growth. According to $\mathrm{H} 1$, we expect $\beta_{1}$ to be positive and statistically significant: $\beta_{1}$ represents the marginal effect of the number of owner-managers on firm's TFP growth. According to $\mathrm{H} 2$, we expect $\beta_{2}$ to be negligible, suggesting that the alleged benefits of a larger number of non-manager individual shareholders are offset by the horizontal agency costs engendered by this type of 'non-managerial' ownership.

With regard to control variables $\left(Z_{i, t}^{j}\right)$, we first include firm creditworthiness (Becchetti and Trovato 2002), measured by the ratio between financial debt and firm's total assets (DebtOnTA $\left.A_{i, t}\right)$ : highly leveraged firms are expected to exhibit better performance than less leveraged firms because of a higher availability of external finance. Moreover, in accordance to Shleifer and Vishny (1997), when leverage is high, the threat of bankruptcy acts as an effective motivating force to make firms more efficient. We also include the ratio between cash flow and sales $\left(\right.$ CFOnSales $\left._{i, t}\right)$, as suggested by Brush et al. (2000): firms with high cash flow ratios are expected to perform better than firms with low cash flow ratios because of a higher availability of internal finance. As is customary in the extant literature, some transformations must be performed for these accounting ratios (DebtOnTA $_{i, t}$ and $\mathrm{CFOnSales}_{i, t}$ ). Because our sample firms are relatively young and small, total assets and sales values may sometimes be close to zero, producing extremely skewed and leptokurtic distributions of the two ratios. The presence of these outliers could severely bias our results. To avoid these problems, we winsorise both ratios with a $1 \%$ cutoff for each tail (e.g., Dixon 1960). ${ }^{10}$ Second, we control for firms' logarithmic age $\left(\ln \mathrm{Age}_{i, t}\right)$ : due to 'learning' effects, older firms might be more efficient than younger ones (Ang et al. 2000; Colombo et al. 2011). Finally, we insert year and regional dummies. ${ }^{11}$

Descriptive statistics of covariates included in our model are reported in Table 2. The median sample firm has two owner-managers. The mean is larger (2.8) as there are a few firms with a rather large number of owner-managers. Note however that $75 \%$ $(90 \%)$ of the sample firms have three (5) ownermanagers or less. Out of the 255 sample firms, only 77 firms $(30.20 \%)$ have at least one non-manager individual shareholder in their equity. This number ranges from 1 to a maximum of 6 non-manager individual share-holders, but in most cases the number of non-manager individual shareholders is small. In fact, the median number of non-manager individual shareholders in those firms in which there is at least one non-manager individual shareholder is equal to 1 .

To explicitly consider the moderating effect of firm leverage on the relationship between the number of non-manager individual shareholders and firm performance, we specify the following model (model II):

$$
\begin{aligned}
\mathrm{TFP}_{i, t}= & \alpha \mathrm{TFP}_{i, t-1}+\beta_{1} \mathrm{OM}_{i, t}+\beta_{2} \mathrm{NMS}_{i, t} \\
& +\beta_{3} \mathrm{NMS}_{i, t} * \operatorname{DebtOnTA}_{i, t}+\delta_{j} Z_{i, t}^{j}+\varepsilon_{i, t} .
\end{aligned}
$$

According to $\mathrm{H} 3$, we expect $\beta_{3}$ to be positive and statistically significant. If $\beta_{2}$ is negative, indicating that in the absence of debt horizontal agency costs

10

In other words, for both ratios, we calculated the values corresponding to the 1st and 99th percentiles of the variable's distribution and assigned these values to all observations falling before the 1st percentile and beyond the 99th percentile, respectively. This approach is useful because it reduces the impact of outliers and allows the use of a larger number of observations than would be possible if the outliers were deleted. As robustness check we use other winsorising thresholds (e.g., 2 and $5 \%$ ). Results are very similar to those reported in the text and are available upon request from the authors. 11

As is customary in this context (e.g., Colombo et al. 2011; Girma et al. 2007), we do not insert industry dummies at the second step because TFP is estimated separately for each industry at the first step. 
Table 2 Descriptive statistics

\begin{tabular}{|c|c|c|c|c|c|c|}
\hline & No. obs. & Mean & Median & SD & Min & Max \\
\hline $\mathrm{TFP}_{i, t}$ & 1,147 & 4.779 & 4.736 & 0.899 & -2.242 & 7.498 \\
\hline $\mathrm{OM}_{i, t}$ & 1,147 & 2.825 & 2.000 & 1.895 & 0.000 & 18.000 \\
\hline $\mathrm{NMS}_{i, t}$ & 1,147 & 0.456 & 0.000 & 0.946 & 0.000 & 6.000 \\
\hline DebtonTA $_{i, t}$ & 1,147 & 0.696 & 0.726 & 0.187 & 0.109 & 1.113 \\
\hline DebtonTA $_{i, t}$ (not winsorized) & 1,147 & 0.696 & 0.726 & 0.189 & 0.062 & 1.479 \\
\hline CFonSales $_{i, t}$ & 1,147 & 0.062 & 0.049 & 0.145 & -1.220 & 0.603 \\
\hline CFonSales $_{i, t}$ (not winsorized) & 1,147 & 0.063 & 0.049 & 0.239 & -3.917 & 3.617 \\
\hline $\operatorname{Age}_{i, t}$ & 1,147 & 9.302 & 8.000 & 5.474 & 2.000 & 23.000 \\
\hline
\end{tabular}

$\mathrm{TFP}_{i, t}$ is the value of the TFP of firm $i$ at time $t ; \mathrm{OM}_{i, t}$ is the number of owner-managers of firm $i$ at time $t$; NMS $i, t$ is the number of non-manager individual shareholders of firm $i$ at time $t$; DebtOnTA $A_{i, t}$ is the ratio between financial debt and firm's total assets of firm $i$ at time $t$ CFOnSales $_{i, t}$ is the ratio between cash flow and sales of firm $i$ at time $t$ Age $_{i, t}$ is the age of firm $i$ at time $t$

related to the presence of non-manager individual shareholders are higher than benefits, we can calculate the minimum level of debt necessary to offset these agency costs through the following non-linear combination of parameters:

DebtOnTA threshold $=-\left(\frac{\beta_{2}}{\beta_{3}}\right)$.

Moreover, to check the robustness of our results, we estimate a different model to measure the effect on firm TFP growth produced by the presence of nonmanager individual shareholders in heavily leveraged firms. We insert the dummy variable d_highlylev ${ }_{i, t}$ that equals 1 if DebtOnTA $A_{i, t}$ is higher than the median value. ${ }^{12}$ We thus estimate the following model (model III):

$$
\begin{aligned}
\mathrm{TFP}_{i, t}= & \alpha \mathrm{TFP}_{i, t-1}+\beta_{1} \mathrm{OM}_{i, t}+\beta_{2} \mathrm{NMS}_{i, t} \\
& +\beta_{4} \mathrm{NMS}_{i, t} * \mathrm{~d} \_ \text {highlylev } \\
i, t & +\delta_{j} Z_{i, t}^{j}+\varepsilon_{i, t} .
\end{aligned}
$$

We can test the null hypothesis that the number of non-manager individual shareholders does not have any effect on firm performance in highly leveraged firms through the following linear combination of parameters (in this model, we also substitute DebtOnTA $_{i, t}$ with d_highylev ditt $_{\text {among the control }}$ variables): $\beta_{2}+\beta_{4}=0$.

\footnotetext{
12 Our results are robust to the use of different thresholds of DebtOnTA $_{i, t}$. Results for thresholds different than the 50th percentile (e.g., 75th, 90th and 95th) are not reported in the text but are available upon request from the authors.
}

\subsection{Estimation method}

The inclusion in our models of the lagged dependent variable among the covariates and the endogenous nature of the relationship between ownership structure and firm performance (Bushee 2004; Demsetz and Villalonga 2001) ${ }^{13}$ require the use of appropriate estimation techniques. To address this endogeneity problem, following the literature on dynamic panel data models (Blundell and Bond 1998), we resort to the system generalised method of moments (GMMSYS) methodology. In the GMM-SYS methodology, additional moment conditions to the difference GMM (Arellano and Bond 1991) are employed using first differences as instruments for variables in levels, starting from $t-2$ for all the endogenous variables (for an application of this procedure in a similar context, see Florackis and Ozkan 2009).

However, the GMM-SYS methodology also has some weaknesses. First, the use of a large number of instruments can result in significant finite sample bias (Roodman 2009). To address this problem, we estimate our models with a reduced instrument set, with moment conditions in the interval between $t-2$ and $t-5$. Second, the moment conditions of the GMMSYS approach are only valid if the instruments are uncorrelated with the error terms. As shown in Sect. 5, results of the Hansen statistic reassure us about the validity of the moment conditions used in all the

\footnotetext{
13 As suggested by Connelly et al. (2010, p. 1563): 'different investors take ownership stakes in companies owing to the presence of certain firm attributes such as performance [...]. More specifically, ownership is not exogenous'.
} 
estimations. Third, the standard GMM-SYS approach allows us to control for the endogeneity of the covariates under the assumption of sequential exogeneity (Wooldridge 2002, p. 300). In fact, this approach assumes that although past shocks to firm performance can affect the number of owners, future shocks to firm performance cannot. However, the number of owners might be positively correlated with future performance shocks if owners are able to select firms with superior business opportunities. In these circumstances, the estimated coefficients of the owners-related variables are upwardly biased. To address these problems, we add two additional groups of variables to the traditional set of instruments of the GMM-SYS estimator. These "external" instruments must be correlated with the owners-related variables but must also be independent of the error terms of Eqs. (3), (4) and (6). The first group of instruments reflects the birth rates and death rates of firms in the geographic area and in the industry in which the focal firm operates (Source: Italian National Institute of Statistics), as proxies of entrepre-neurial activism at time $t$. The second group of additional instruments measures the amount of bank deposits per capita in year $t$ in the geographic area in which the focal firm is located. This instrument is defined as the ratio between the amount of bank deposits of region $i$ in year $t$ (source: Bank of Italy) and the total population of region $i$ in year $t$ (source: Italian National Institute of Statistics).

\subsection{Test for survivorship bias}

To test for a potential survivorship bias in our data, we adapt to our specific framework the procedure developed by Semykina and Wooldridge (2010). The authors extend Wooldridge's (1995) standard variable addition test for selection bias in panel data in the presence of unobserved heterogeneity and endogenous regressors. More specifically, we compute an inverse Mills ratio (IMR) variable for firm exit at time $t$ for each of the 255 firms included in our sample. ${ }^{14}$ This time-varying ratio is then inserted as a control for survivorship bias in the main equations [Eqs. (3), (4), (6)]. As shown in Sect. 5 (Tables 3, 4, 5), the absence

\footnotetext{
14 Out of 255 sample firms, we are able to estimate the IMRtype variable for 251 firms. For more details on the estimation of the IMR-type variable on the same data set, see, e.g., Colombo et al. $(2009,2011)$.
}

of statistical significance of the coefficient of IMR reassures us that survivorship bias does not significantly affect our results.

\section{Results and discussion}

Econometric results are reported in Tables 3, 4 and 5. In the first two columns, we show estimation results obtained through the GMM-SYS estimator with the traditional set of instruments [model I (a)] and with the inclusion of 'external' instruments [model I (b)], respectively. In the third column, we test for the presence of survivorship bias in our data [model I (c)]. Estimates of Eq. (3) are reported in Table 3.

With regard to the coefficient of the $\mathrm{OM}_{i, t}$ variable, our estimates suggest that the size of the ownermanagers' team positively influences firm performance. In fact, the coefficient $\beta_{1}$ is positive and statistically significant at conventional confidence levels. Owners who are actively involved in management activities help to fill the firm's knowledge and funding gaps and contribute to enhance firm performance because of low horizontal agency costs. Our first research hypothesis is supported. Moreover, the coefficients of $\mathrm{OM}_{i, t}$ can be interpreted as semielasticity measures: on average, the addition of a new owner-manager produces an increase in TFP growth equal to $6.8 \%$ points (values range from +6.5 to +6.9 $\%)$. In unreported regressions, we add to the model specification the squared term of $\mathrm{OM}_{i, t}$ to test for potential non-linearities in the relation between the size of the owner-managers' team and firm performance. The squared term was not found to be significant, thus confirming that our sample firms lay on the increasing part of the (alleged) inverse Ushaped curve describing the relationship between the number of owner-managers and firm performance. Results of the estimates are available upon request from the authors. ${ }^{15}$ The results in Table 3 show that our second hypothesis is supported as well: the number of non-manager individual shareholders has a negligible effect on TFP growth. We explain this result by considering that, compared with ownermanagers, a higher number of owners with no active role in a firm's management entails two differences.

${ }^{15}$ We are grateful to an anonymous referee for this suggestion. 
Table 3 The impact of ownership structure on TFP growth (model I)

\begin{tabular}{|c|c|c|c|c|}
\hline & Coeff. & $\begin{array}{l}\text { Model I } \\
\text { (a) }\end{array}$ & $\begin{array}{l}\text { Model I } \\
\text { (b) }\end{array}$ & $\begin{array}{l}\text { Model I } \\
\text { (c) }\end{array}$ \\
\hline $\mathrm{TFP}_{i, t-1}$ & $\alpha$ & $\begin{array}{l}0.542 * * * \\
(0.055)\end{array}$ & $\begin{array}{l}0.583 * * * \\
(0.055)\end{array}$ & $\begin{array}{l}0.543 * * * \\
(0.054)\end{array}$ \\
\hline $\mathrm{OM}_{i, t}$ & $\beta_{1}$ & $\begin{array}{l}0.068 * * \\
(0.033)\end{array}$ & $\begin{array}{l}0.065^{*} \\
(0.036)\end{array}$ & $\begin{array}{l}0.069 * * \\
(0.034)\end{array}$ \\
\hline $\mathrm{NMS}_{i, t}$ & $\beta_{2}$ & $\begin{array}{l}-0.001 \\
(0.090)\end{array}$ & $\begin{array}{l}-0.017 \\
(0.079)\end{array}$ & $\begin{array}{l}0.010 \\
(0.111)\end{array}$ \\
\hline DebtOnTA $_{i, t}$ & & $\begin{array}{l}0.376 \\
(0.357)\end{array}$ & $\begin{array}{l}0.426 \\
(0.357)\end{array}$ & $\begin{array}{l}0.377 \\
(0.427)\end{array}$ \\
\hline CFOnSales $_{i, t}$ & & $\begin{array}{l}0.589 * * * \\
(0.177)\end{array}$ & $\begin{array}{l}0.601 * * * \\
(0.170)\end{array}$ & $\begin{array}{l}0.590 * * * \\
(0.201)\end{array}$ \\
\hline $\ln \mathrm{Age}_{i, t}$ & & $\begin{array}{l}0.112 * * * \\
(0.039)\end{array}$ & $\begin{array}{l}0.103 * * * \\
(0.037)\end{array}$ & $\begin{array}{l}0.115 * * \\
(0.053)\end{array}$ \\
\hline $\mathrm{IMR}_{i, t}$ & & & & $\begin{array}{l}0.069 \\
(0.384)\end{array}$ \\
\hline $\begin{array}{l}\text { Region } \\
\text { dummies }\end{array}$ & & YES & YES & YES \\
\hline $\begin{array}{l}\text { Year } \\
\text { dummies }\end{array}$ & & YES & YES & YES \\
\hline Obs. & & 1147 & 1147 & 1127 \\
\hline Groups & & 255 & 255 & 251 \\
\hline AR1 & & -1.172 & -1.123 & -1.171 \\
\hline AR2 & & -0.621 & -0.519 & -0.652 \\
\hline Hansen & & $\begin{array}{c}127.305 \\
{[117]}\end{array}$ & $\begin{array}{c}128.101 \\
{[121]}\end{array}$ & $\begin{array}{c}126.324 \\
{[116]}\end{array}$ \\
\hline
\end{tabular}

Estimates of model I. Variables are defined in Sect. 4.2. Region and year dummies and the constant term are omitted in the table but included in the estimates. As regards coefficient $\alpha$, we test the null hypothesis $\mathrm{H} 0: \alpha=1$. Robust standard errors in round brackets; degrees of freedom in squared brackets. $* * *$,

$* *$ and $*$ indicate significance levels of $<1,<5$ and $<10 \%$, respectively. Estimates are derived from the two-step system GMM estimator with finite sample correction (Windmeijer 2005). AR1 and AR2 are tests of the null hypothesis of no firstand second-order serial correlation, respectively. Hansen is a test of the validity of the overidentifying restrictions based on the efficient two-step system GMM estimator. GMM instruments start from $t-2$ and are limited to $t-5$

First, non-manager individual shareholders are likely to provide to the firm a lower level of resources and competences than owner-managers do because they are not involved in the firm's management. Second, non-manager individual shareholders are unable to properly monitor owner-managers. As a consequence, their presence engenders horizontal agency costs at a detriment to firm performance.
To test hypothesis H3, we now turn to the model II, which is described by Eq. (4). The results are reported in Table 4. First, our first research hypothesis still holds, and the magnitude of the coefficients of $\mathrm{OM}_{i, t}$ is very similar to what is shown in Table 3 . In fact, the coefficient $\beta_{1}$ is positive and statistically significant, and its value ranges between +7 and $+7.8 \%$. In these models, the effect of the number of non-manager individual shareholders depends on firm's leverage. When the focal firm is not leveraged (i.e., the amount of financial debt is equal to 0 ), this effect is given by the coefficient $\beta_{2}$. This coefficient is negative and not significant at conventional confidence levels. It thus appears that, in non-leveraged firms, the number of non-manager individual shareholders does not significantly influence firm performance. Conversely, the coefficient $\beta_{3}$ is positive but not statistically significant. This result provides an (admittedly weak) indication that the effect on firm performance of the number of non-manager individual shareholders depends on firm's leverage. In particular, according to our results, when DebtOnTA $A_{i, t}$ is between 0.567 and 0.667 , the disciplining role of bank debt is effective in offsetting the horizontal agency costs between ownermanagers and non-manager individual shareholders (the results are reported at the bottom of Table 4). It is interesting that this financial debt ratio is approximately the 40th percentile of DebtOnTA ${ }_{i, t}$ in our sample (see Table 2).

To further investigate the moderating effect of leverage, we estimate the effect of the number of nonmanager individual shareholders in highly leveraged firms, following the model described by Eq. (6). To define highly leveraged firms, we use the 50th percentile of DebtOnTA $A_{i, t}$, a procedure that is widely used in the finance literature (e.g., Faulkender and Petersen 2006). The results of model III are reported in Table 5. In all of these models, $\beta_{1}$ is again positive and statistically significant at conventional confidence levels. Moreover, its magnitude is in the same range as those shown above (the effect on TFP growth is found to be between +5.9 and $+6.4 \%$ ). With regard to the effect of the number of non-manager individual shareholders, the coefficient $\beta_{2}$ remains negative and not statistically significant. This result confirms that the number of non-manager individual shareholders has no impact on TFP growth among non-highly leveraged firms. This result still indicates that in low- 
Table 4 The disciplining role of debt (model II)

\begin{tabular}{|c|c|c|c|c|}
\hline & Coeff. & Model II (a) & Model II (b) & Model II (c) \\
\hline $\mathrm{TFP}_{i, t-1}$ & $\alpha$ & $\begin{array}{l}0.533 * * * \\
(0.054)\end{array}$ & $\begin{array}{l}0.574 * * * \\
(0.056)\end{array}$ & $\begin{array}{l}0.532 * * * \\
(0.058)\end{array}$ \\
\hline $\mathrm{OM}_{i, t}$ & $\beta_{1}$ & $\begin{array}{l}0.076^{* *} \\
(0.034)\end{array}$ & $\begin{array}{l}0.070 * * \\
(0.035)\end{array}$ & $\begin{array}{l}0.078 * * \\
(0.037)\end{array}$ \\
\hline $\mathrm{NMS}_{i, t}$ & $\beta_{2}$ & $\begin{array}{r}-0.156 \\
(0.163)\end{array}$ & $\begin{array}{r}-0.103 \\
(0.163)\end{array}$ & $\begin{array}{r}-0.159 \\
(0.160)\end{array}$ \\
\hline $\mathrm{NMS}_{i, t} *$ DebtOnTA $_{i, t}$ & $\beta_{3}$ & $\begin{array}{c}0.244 \\
(0.202)\end{array}$ & $\begin{array}{c}0.154 \\
(0.200)\end{array}$ & $\begin{array}{c}0.281 \\
(0.184)\end{array}$ \\
\hline DebtOnTA $_{i, t}$ & & $\begin{array}{c}0.180 \\
(0.553)\end{array}$ & $\begin{array}{c}0.323 \\
(0.556)\end{array}$ & $\begin{array}{c}0.183 \\
(0.532)\end{array}$ \\
\hline CFOnSales $_{i, t}$ & & $\begin{array}{l}0.583 * * * \\
(0.202)\end{array}$ & $\begin{array}{l}0.613 * * * \\
(0.210)\end{array}$ & $\begin{array}{l}0.551 * * * \\
(0.201)\end{array}$ \\
\hline $\ln \mathrm{Age}_{i, t}$ & & $\begin{array}{l}0.114 * * \\
(0.048)\end{array}$ & $\begin{array}{l}0.104 * * \\
(0.045)\end{array}$ & $\begin{array}{c}0.095 * \\
(0.048)\end{array}$ \\
\hline $\mathrm{IMR}_{i, t}$ & & & & $\begin{array}{r}-0.186 \\
(0.471)\end{array}$ \\
\hline Region dummies & & YES & YES & YES \\
\hline Year dummies & & YES & YES & YES \\
\hline Obs. & & 147 & 1147 & 1127 \\
\hline Groups & & 255 & 255 & 251 \\
\hline AR1 & & -1.075 & -1.065 & -1.088 \\
\hline AR2 & & -0.703 & -0.593 & -0.753 \\
\hline Hansen & & 159.566 [149] & 161.615 [153] & $156.694[148]$ \\
\hline DebtOnTA threshold & $-\left(\frac{\beta_{2}}{\beta_{3}}\right)$ & 0.641 & 0.667 & 0.567 \\
\hline
\end{tabular}

Estimates of model II. Variables are defined in Sect. 4.2. Region and year dummies and the constant term are omitted in the table but included in the estimates. As regards coefficient $\alpha$, we test the null hypothesis H0: $\alpha=1$. Robust standard errors in round brackets; degrees of freedom in squared brackets. $* * *, * *$ and $*$ indicate significance levels of $<1,<5$ and $<10 \%$, respectively. Estimates are derived from the two-step system GMM estimator with finite sample correction (Windmeijer 2005). AR1 and AR2 are tests of the null hypothesis of no first- and second-order serial correlation, respectively. Hansen is a test of the validity of the overidentifying restrictions based on the efficient two-step system GMM estimator. GMM instruments start from $t-2$ and are limited to $t-5$

leveraged firms, the horizontal agency costs engendered by the presence of non-manager individual shareholders offset the benefits related to the resources brought in the firm by these owners. More interestingly, $\beta_{4}$ is positive and statistically significant, pointing to a positive moderating effect played by financial debt. In other words, our results suggest that the effect of the number of non-manager individual shareholders on firm performance is significantly greater if firms are highly leveraged. Note also that the estimated improvement is economically relevant (between +20.6 and $+29.7 \%$ ). However, as documented by the Wald tests at the bottom of Table 5, the overall effect of the number of non-manager individ-ual shareholders on TFP growth is not significant even among highly leveraged firms. In fact, the linear combination of the coefficients $\beta_{2}$ and $\beta_{4}$ (see Sect. 4.2) is not statistically significant.

As a further robustness test, we inserted in the specification of model II (III) the interactive term $\mathrm{OM}_{i, t}$ * DebtOnTA $A_{i, t}\left(\mathrm{OM}_{i, t} *\right.$ d_highlylev_50 $\left.0_{i, t}\right)$ to assess whether firm leverage also moderated the performance impact of the number of owner-managers. These two terms were not found to be statistically significant, in accordance with the view that the number of ownermanagers does not affect the extent 
Table 5 The disciplining role of debt (model III)

\begin{tabular}{|c|c|c|c|c|}
\hline & Coeff. & Model III (a) & Model III (b) & Model III (c) \\
\hline $\mathrm{TFP}_{i, t-1}$ & $\alpha$ & $\begin{array}{l}0.559 * * * \\
(0.064)\end{array}$ & $\begin{array}{l}0.596 * * * \\
(0.065)\end{array}$ & $\begin{array}{l}0.559 * * * \\
(0.063)\end{array}$ \\
\hline $\mathrm{OM}_{i, t}$ & $\beta_{1}$ & $\begin{array}{l}0.064 * * * \\
(0.023)\end{array}$ & $\begin{array}{l}0.061 * * * \\
(0.023)\end{array}$ & $\begin{array}{l}0.059 * * * \\
(0.023)\end{array}$ \\
\hline $\mathrm{NMS}_{i, t}$ & $\beta_{2}$ & $\begin{array}{r}-0.111 \\
(0.071)\end{array}$ & $\begin{array}{r}-0.103 \\
(0.063)\end{array}$ & $\begin{array}{r}-0.102 \\
(0.074)\end{array}$ \\
\hline $\mathrm{NMS}_{i, t} *$ d_highlylev_50 $0_{i, t}$ & $\beta_{4}$ & $\begin{array}{l}0.297 * * * \\
(0.104)\end{array}$ & $\begin{array}{c}0.206^{* *} \\
(0.087)\end{array}$ & $\begin{array}{l}0.293 * * \\
(0.129)\end{array}$ \\
\hline d_highlylev_50 ${ }_{i, t}$ & & $\begin{array}{r}-0.155 \\
(0.096)\end{array}$ & $\begin{array}{r}-0.095 \\
(0.081)\end{array}$ & $\begin{array}{r}-0.125 \\
(0.098)\end{array}$ \\
\hline CFOnSales $_{i, t}$ & & $\begin{array}{l}0.526 * * * \\
(0.187)\end{array}$ & $\begin{array}{l}0.547 * * * \\
(0.184)\end{array}$ & $\begin{array}{l}0.552 * * \\
(0.236)\end{array}$ \\
\hline $\ln \mathrm{Age}_{i, t}$ & & $\begin{array}{c}0.059 \\
(0.044)\end{array}$ & $\begin{array}{c}0.050 \\
(0.042)\end{array}$ & $\begin{array}{c}0.073 \\
(0.056)\end{array}$ \\
\hline $\mathrm{IMR}_{i, t}$ & & & & $\begin{array}{c}0.116 \\
(0.353)\end{array}$ \\
\hline Region dummies & & YES & YES & YES \\
\hline Year dummies & & YES & YES & YES \\
\hline Obs. & & 1147 & 1147 & 1127 \\
\hline Groups & & 255 & 255 & 251 \\
\hline AR1 & & -1.155 & -1.097 & -1.138 \\
\hline AR2 & & -0.511 & -0.462 & -0.495 \\
\hline Hansen & & 148.869 [149] & $150.746[153]$ & $151.510[148]$ \\
\hline $\mathrm{NMS}_{i, t}$ in highly leveraged firms & $\beta_{2}+\beta_{4}$ & $\begin{array}{c}0.187 \\
(0.121)\end{array}$ & $\begin{array}{c}0.103 \\
(0.103)\end{array}$ & $\begin{array}{c}0.191 \\
(0.147)\end{array}$ \\
\hline
\end{tabular}

Estimates of model III. Variables are defined in Sect. 4.2. Region and year dummies and the constant term are omitted in the table but included in the estimates. As regards coefficient $\alpha$, we test the null hypothesis H0: $\alpha=1$. Robust standard errors in round brackets; degrees of freedom in squared brackets. $* * *, * *$ and $*$ indicate significance levels of $<1,<5$ and $<10 \%$, respectively. Estimates are derived from the two-step system GMM estimator with finite sample correction (Windmeijer 2005). AR1 and AR2 are tests of the null hypothesis of no first- and second-order serial correlation, respectively. Hansen is a test on the validity of the overidentifying restrictions based on the efficient two-step system GMM estimator. GMM instruments start from $t-2$ and are limited to $t-5$

of horizontal agency costs. The remaining results were unchanged.

As to the control variables included in all specifications, first of all, the coefficients of the TFP level at time $t-1(\alpha)$ are significantly lower than unity (at $1 \%$ ), indicating that the growth and level of TFP are negatively related in our sample. Second, our estimates show that firm age generally has a positive impact on firm performance, in line with the existence of learning effects that make older firms more efficient than younger ones. Third, as expected, having a higher cash flow ratio improves firm performance. Conversely, financial debt does not appear to directly influence TFP growth. This result is in line with Becchetti and Trovato (2002) who argue that external finance does not matter in explaining firm performance. ${ }^{16}$

${ }^{16}$ In order to exclude a reverse causality relationship between firm's leverage and performance, we re-estimated our models by replacing either DebtOnTA ${ }_{i, t}$ or d_highlylev_50 $0_{i, t}$ with their lagged values, respectively. Results do not change, confirming the absence of a significant direct effect of firm leverage on productivity growth in our sample. As a further robustness check, we performed a Granger causality test between firm's leverage and performance, which still excludes reverse causality concerns. We are grateful to an anonymous referee for this suggestion. 
As to the test for survivorship bias, the coefficient of the additional variable included in the estimates $\left(\mathrm{IMR}_{i, t}\right)$ is not statistically significant in any specifications. Thus, we can safely exclude the presence of any remarkable survivorship bias in our data. Moreover, the inclusion of $\mathrm{IMR}_{i, t}$ does not seem to influence our results.

Notably, with regard to the validity of GMM-SYS estimations, Hansen tests are passed in all specifications. AR2 tests exclude the presence of first-order serial correlation. The autoregressive coefficient in all specifications is not close to unity, thus excluding stationarity problems. We also performed pseudofirst-stage regressions to test the 'goodness' of our instruments. Such regressions show a stronger relevance of lagged instruments in first differences, thus pointing to the effectiveness of GMM-SYS methodology. Moreover, pseudo-first-stage regressions highlight a strong explanatory power of the "external" instruments. For the sake of synthesis, we do not report pseudo-first-stage regressions in the text. They are available upon request from the authors.

We also check for two potential sources of bias in our sample: the presence of family firms and/or institutional investors (results of these two robustness checks are not reported in the text but are available upon request from the authors). First, the extant literature on family firms argues that horizontal agency costs in this type of firms may differ from those in non-family firms. On the one hand, Fama and Jensen (1983, p. 8) assert that special relations among decision agents allow family firms to efficiently monitor family agents' conduct and settle disputes. Each family member acts in the belief that she/he has a residual claim on the family's estate (Holtz-Eakin et al. 1993; Stark and Falk 1998). This should align the interests among the family agents, thereby reducing horizontal agency costs. On the other hand, Schulze et al. (2002) affirm that interests' alignment holds in the start-up phase only. In later phases, family agents tend to exacerbate horizontal agency problems because of high levels of ownership concentration and incentives that favour high levels of perk consumption. The RITA data set contains information on the familiness of high-tech entrepreneurial firms. As is customary in the extant literature (e.g., Chua et al. 1999), firms are classified as family firms if the family owns at least 50 $\%$ of equity. In our sample, there are only 22 family firms (out of 255 firms). On average, family firms have 2.37 owner-managers. Out of these 22 firms, 5 have at least one non-manager individual shareholder (the range is from 1 to $4 ; 2.12$ non-manager individual shareholders on average). When re-estimating our models with the exclusion of family firms, results are very similar to those previously discussed, thus excluding a bias in our results due to the presence of family firms. Second, our sample includes firms backed by institutional investors, i.e., venture capital (VC) investors. In particular, 16 firms received VC during their life (out of 255 firms). On average, VC-backed firms have 3.57 owner-managers. Out of 16 VC-backed firms, 4 have at least one non-manager individual shareholder (the range is from 1 to $4 ; 3.18$ non-manager individual shareholders on average). However, when excluding VC-backed firms from our estimates, results are very similar to those previously discussed. ${ }^{17}$

Lastly, one may argue that owner-managers provide to their firms both human capital and financial resources. Hence, a higher number of owner-managers may lead to improvements in both the output side (i.e., due to better products that command higher prices and/or greater market coverage) and in the input side (i.e., a more efficient use of production inputs). Conversely, since the main contribution of nonmanager individual shareholders is an increase of financial resources, a higher number of this type of owners may end up with a better sales growth performance, in the absence of any TFP growth. Hence, following a well-grounded tradition in the entrepreneurship literature (e.g., Chandler et al. 2009; Colombo and Grilli 2005; Delmar 1997; Wiklund and Shepherd 2003a, b), we re-run estimates of model II while employing sales growth as an alternative performance measure. The results (illustrated in Table 6 in the Appendix) are in line with those relating to the TFP growth measure, reassuring us about the reliability of our main depen-dent variable. In particular, the number of owner-managers has a positive and highly significant effect on sales growth, whose magnitude (around $+10 \%$ ) is even greater than the one of the effect on TFP growth. Conversely, there is no evidence of a positive effect on sales growth of the number of non-manager individual shareholders.

${ }^{17}$ We also estimated our models by excluding VC-backed firms from the year in which they received the first round of VC financing only. Results do not change. 


\section{Conclusions}

In recent years, governance research has grown in importance (Bertoni et al. 2012), and the role of ownership structure on firm performance is a central issue in this research stream (Connelly et al. 2010). Previous studies have examined mature companies (Villalonga and Amit 2006) and have used samples of listed (Demsetz and Villalonga 2001) or IPO firms (Brau et al. 2004; Filatotchev et al. 2006).

In this article, we have focused on unlisted hightech entrepreneurial firms. More specifically, we have investigated the effect of the presence of two different types of individual owners on firm performance: owner-managers and non-manager individual shareholders. The overall effect of these two types of owners on firm performance is given by the balance between the benefits of the resources and competencies provided by the focal owner and the costs associated with horizontal agency problems between different owners.

We have tested our research hypotheses on a sample of 255 Italian high-tech entrepreneurial firms observed from 1994 (or from their foundation) to 2003. The rather long longitudinal dimension of the data set and the availability of a rich set of firmspecific variables have allowed us to employ system GMM methodology and to effectively control for the endogenous nature of the relationship between ownership structure and firm performance.

The article provides interesting new insights. First, firms with a higher number of owner-managers exhibit better performance, in line with the view that the higher number of owner-managers enlarges the set of firm's resources and competences with no significant increase of horizontal agency costs. To our knowledge, our study is the first large-scale empirical analysis of this issue within a proper panel data framework. ${ }^{18}$ Second, the number of non-manager

18 A partial exception is represented by the work of Sine et al. (2006). The authors consider the number of executives in the founding team divided by the number of employees and find that this variable is positively related to the performance of Internet firms as measured by firm's revenues. individual shareholders does not significantly influence firm performance. We interpret this result as evidence that the benefits associated with the resources non-manager individual shareholders provide to the firm are offset by an increase in horizontal agency costs, engendered by the limited ability of nonmanager individual shareholders to effectively monitor the (potentially) opportunistic behaviour of owner-managers. However, banks' close monitoring and the self-discipline imposed on owner-managers' conduct by a high level of leverage act as control mechanisms that reduce the amount of horizontal agency costs arising from the presence of nonmanager individual shareholders. In other words, when a firm's debt position worsens, owner-managers increase their efforts to improve firm efficiency as a result of both the threat of bankruptcy and the banks' closer monitoring. Consequently, the performance impact of non-manager individual shareholders is more positive for highly leveraged firms than for other firms. This notwithstanding, we failed to detect a positive and significant effect of the presence of nonmanager individual shareholders even for highly leveraged firms.

We are aware that this study has some limitations, which open up opportunities for future research. First, in this article we considered Italian entrepreneurial firms. This raises the issue of whether our results are generalisable to other countries and institutional contexts. As suggested by Bruton et al. (2010, p. 492): 'the institutional setting in which research is conducted may impact the nature and extent of agency conflicts and the governance roles of ownership patterns'. Second, it would be interesting to investigate whether the results we obtained here depend on the amount of financial resources provided by each type of owner. Through the use of TFP growth, we control for funding injections provided by the owners by scaling sales growth with the growth in inputs. However, if data on financial amounts provided by different types of owners were available, one could assess whether our results are driven by 'financial' effects. Third, previous studies indicate that nonmanager individual shareholders are an heterogeneous category (Shane 2012). It would then be interesting to assess whether their characteristics, e.g., in terms of education, work experience and investment objectives, influence their incentives and ability to monitor firms' operations and thus lower horizontal agency 
costs. Fourth, data on the ownership shares possessed by each individual owner were unfortunately not available for this study. Therefore, we could not examine the role of ownership concentration, which clearly influences horizontal agency costs. In particular, one may presume that the horizontal agency costs engendered by the presence of non-manager individual shareholders are lower if these latter have the opportunity to form a controlling coalition with other shareholders.

Despite the above-mentioned limitations, the new insights provided by this study on the impact of different types of owner on high-tech entrepreneurial firms' performance have important practical implications for both entrepreneurs and policy makers. Entrepreneurs should clearly bear in mind that obtaining external capital from 'passive' individual shareholders is not a panacea, as this move generates horizontal agency costs that often outweigh potential benefits. Conversely, enlarging the team of ownermanagers does have a positive impact on firm performance. Previous studies have documented the difficulties high-tech entrepreneurial firms encounter in expanding their competencies through the recruitment of salaried managers (Colombo and Grilli 2013). Enlarging the team of owner-managers allows these firms to circumvent these difficulties and has the additional advantage of increasing the available financial resources.

Lastly, let us consider policy implications. With traditional venture capital investors being able or willing to provide seed capital only to a tiny fraction of the entrepreneurial firms that demand external finance, policy makers are increasingly turning their attention to informal venture capital provided by business angels and, more generally, individual investors (OECD 2012). It is common wisdom in policy circles that entrepreneurial firms would greatly benefit from rapidly opening their capital to this type of investors. Accordingly, in several countries policy schemes have been designed to favour investments in entrepreneur-ial firms by individual investors. ${ }^{19}$ These policy

\footnotetext{
19 The TEPA law introduced in France in 2007 is a typical example. A $50 \%$ share of the money invested by tax payers in the capital of unlisted SMEs on a long-term basis (i.e., the lockup period is 5 year long) will be deducted from the solidarity tax on wealth (Impôt de solidarité sur la fortune), up to 45,000 euros per year.
}

schemes have raised some scepticism among scholars: "Encouraging individuals to make such small investments may be counter-productive and socially wasteful if the financial returns are unsatisfactory and the companies financed are not viable" (Lerner 1998, p. 779). Our results cast additional doubts on these policy schemes, showing that the presence of nonmanager individual shareholders does not lead to any efficiency increase. Conversely, previous studies have provided evidence that financing obtained from professionally organised and managed groups of angel investors has a positive impact on investee firms' performance in terms of survival, growth, innovation and successful exit (Kerr et al. 2011). On the one hand, these angel investors allegedly provide mentoring and business contacts that are very valuable to entrepre-neurial firms in the early stages of their life. On the other hand, they are also able to effectively monitor owner-managers, limiting the extent of horizontal agency costs, something that other non-manager individual shareholders are unable to do. Therefore, the key challenge for policy makers is to design policy schemes that encourage investments in entrepreneur-ial ventures by smart individual investors in a discriminating way. ${ }^{20}$

\section{Appendix}

See Table 6.
20 The creation of the European Angels Fund by the European Investment Fund is a step in the right direction. The European Angels Fund (http://www.eif.org/what_we_do/equity/eaf/ index.htm) provides equity to business angels and other noninstitutional investors for the financing of innovative companies through the establishment of co-investment framework agreements. No management fee is paid to the business angel but investment-related costs are shared on a pro-rata basis. Carry payments from the European Angels Fund to the business angel increase the upsides of the investments for the latter. Partner business angels are selected on the basis of their experience in the targeted investment area and track record of successful investments. The scheme is presently active in Germany and Spain. 
Table 6 The impact of ownership structure on sales growth

\begin{tabular}{|c|c|c|c|c|}
\hline & Coeff. & $\begin{array}{l}\text { Model II } \\
\text { (a) }\end{array}$ & $\begin{array}{l}\text { Model II } \\
\text { (b) }\end{array}$ & $\begin{array}{l}\text { Model II } \\
\text { (c) }\end{array}$ \\
\hline Sales $_{i, t-1}$ & $\alpha$ & $\begin{array}{l}0.324 * * * \\
(0.093)\end{array}$ & $\begin{array}{l}0.353 * * * \\
(0.100)\end{array}$ & $\begin{array}{l}0.359 * * * \\
(0.109)\end{array}$ \\
\hline $\mathrm{OM}_{i, t}$ & $\beta_{1}$ & $\begin{array}{l}0.110 * * * \\
(0.041)\end{array}$ & $\begin{array}{l}0.097 * * \\
(0.041)\end{array}$ & $\begin{array}{l}0.110 * * * \\
(0.042)\end{array}$ \\
\hline $\mathrm{NMS}_{i, t}$ & $\beta_{2}$ & $\begin{array}{c}-0.530 * * \\
(0.263)\end{array}$ & $\begin{array}{r}-0.432 \\
(0.267)\end{array}$ & $\begin{array}{r}-0.514 * \\
(0.265)\end{array}$ \\
\hline $\begin{array}{l}\mathrm{NMS}_{i, t} * \\
\text { DebtOnTA }_{i, t}\end{array}$ & & $\begin{array}{c}0.436 \\
(0.385)\end{array}$ & $\begin{array}{c}0.261 \\
(0.385)\end{array}$ & $\begin{array}{c}0.413 \\
(0.389)\end{array}$ \\
\hline DebtOnTA $_{i, t}$ & & $\begin{array}{r}-1.120 * \\
(0.644)\end{array}$ & $\begin{array}{r}-0.869 \\
(0.644)\end{array}$ & $\begin{array}{r}-1.185^{*} \\
(0.719)\end{array}$ \\
\hline CFOnSales $_{i, t}$ & & $\begin{array}{c}0.121 \\
(0.279)\end{array}$ & $\begin{array}{c}0.130 \\
(0.298)\end{array}$ & $\begin{array}{c}0.109 \\
(0.325)\end{array}$ \\
\hline $\ln \operatorname{Age}_{i, t}$ & & $\begin{array}{l}0.452 * * * \\
(0.118)\end{array}$ & $\begin{array}{l}0.415 * * * \\
(0.126)\end{array}$ & $\begin{array}{l}0.428 * * \\
(0.167)\end{array}$ \\
\hline $\mathrm{IMR}_{i, t}$ & & & & $\begin{array}{c}0.101 \\
(0.753)\end{array}$ \\
\hline $\begin{array}{l}\text { Region } \\
\text { dummies }\end{array}$ & & YES & YES & YES \\
\hline Year dummies & & YES & YES & YES \\
\hline Obs. & & 1446 & 1446 & 1421 \\
\hline Groups & & 255 & 255 & 251 \\
\hline AR1 & & -1.36 & -1.327 & -1.339 \\
\hline AR2 & & -1.206 & -1.207 & -1.232 \\
\hline Hansen & & $\begin{array}{r}185.849 \\
{[160]}\end{array}$ & $\begin{array}{r}191.094 \\
{[164]}\end{array}$ & $\begin{array}{r}182.323 \\
\text { [159] }\end{array}$ \\
\hline $\begin{array}{r}\text { DebtOnTA } \\
\text { threshold }\end{array}$ & $-\left(\frac{\beta_{2}}{\beta_{3}}\right)$ & 1.215 & 1.246 & 1.653 \\
\hline
\end{tabular}

Estimates of model II. Variables are defined in Sect. 4.2. Region and year dummies and the constant term are omitted in the table but included in the estimates. As regards coefficient $\alpha$, we test the null hypothesis H0: $\alpha=1$. Robust standard errors in round brackets; degrees of freedom in squared brackets. ***,

$* *$ and $*$ indicate significance levels of $<1,<5$ and $<10 \%$, respectively. Estimates are derived from the two-step system GMM estimator with finite sample correction (Windmeijer 2005). AR1 and AR2 are tests of the null hypothesis of no firstand second-order serial correlation, respectively. Hansen is a test on the validity of the overidentifying restrictions based on the efficient two-step system GMM estimator. GMM instruments start from $t-2$ and are limited to $t-5$

\section{References}

Acs, Z., \& Audretsch, D. (2003). Handbook of entrepreneurship research: An interdisciplinary survey and introduction.

New York: Springer.

Aghion, P., Blundell, R., Griffith, R., Howitt, P., \& Prantl, S. (2009). The effects of entry on incumbent innovation and productivity. Review of Economics and Statistics, 91(1), 20-32.

Aghion, P., \& Tirole, J. (1997). Formal and real authority in organizations. Journal of Political Economy, 105, 1-29.

Aitken, B. J., \& Harrison, A. E. (1999). Do domestic firms benefit from direct foreign investment? Evidence from Venezuela. American Economic Review, 89(3), 605-618.

Ang, J. S., Cole, R. A., \& Lin, J. W. (2000). Agency costs and ownership structure. The Journal of Finance, 55(1), 81-106.

Arellano, M., \& Bond, S. R. (1991). Some tests of specification for panel data: Monte Carlo evidence and an application to employment equations. Review of Economic Studies, 58, 277-297.

Audretsch, D. B. (1995). Innovation, growth and survival. International Journal of Industrial Organization, 13(4), 441-457.

Autio, E., \& Parhankangas, A. (1998). Employment generation potential of new, technology-based firms during a recessionary period: The case of Finland. Small Business Economics, 11(2), 113-123.

Barney, J. (1991). Firm resources and sustained competitive advantage. Journal of Management, 17(1), 99-120.

Barney, J., Wright, M., \& Ketchen, D. J., Jr. (2001). The resource-based view of the firm: Ten years after 1991. Journal of Management, 27, 625-641.

Becchetti, L., \& Trovato, G. (2002). The determinants of growth for small and medium sized firms. The role of the availability of external finance. Small Business Economics, 19(4), 291-306.

Bertoni, F., Colombo, M. G., \& Croce, A. (2010). The effect of Venture Capital financing on the sensitivity to cash flow of firm's investments. European Financial Management, 16(4), 528-551.

Bertoni, F., Colombo, M. G., \& Croce, A. (2012). Corporate governance in high-tech firms. In M. Wright, D. S. Siegel, K. Keasey, \& I. Filatotchev (Eds.), The Oxford handbook of corporate governance (forthcoming).

Blundell, R., \& Bond, S. (1998). Initial conditions and moment restrictions in dynamic panel data models. Journal of Econometrics, 87(1), 115-143.

Brau, J. C., Brown, R. A., \& Osteryoung, J. S. (2004). Do venture capitalists add value to small manufacturing firms? An empirical analysis of venture and nonventure capitalbacked initial public offerings. Journal of Small Business Management, 42(1), 78-92.

Brush, T. H., Bromiley, P., \& Hendrickx, M. (2000). The free cash flow hypothesis for sales growth and firm performance. Strategic Management Journal, 21(4), 455-472.

Bruton, G. D., Filatotchev, I., Chahine, S., \& Wright, M. (2010). Governance, ownership structure, and performance of IPO firms: The impact of different types of private equity investors and institutional environments. Strategic Management Journal, 31, 491-509.

Bushee, B. J. (2004). Identifying and attracting the "right" investors: Evidence on the behavior of institutional investors. Journal of Applied Corporate Finance, 16, 28-35.

Carpenter, R. E., \& Petersen, B. C. (2002a). Capital market imperfections, high-tech investment, and new equity financing. Economic Journal, 112, F54-F72.

Carpenter, R. E., \& Petersen, B. C. (2002b). Is the growth of small firms constrained by internal finance? The Review of Economics and Statistics, 84(2), 298-309. 
Chandler, G. N., McKelvie, A., \& Davidsson, P. (2009). Asset specificity and behavioral uncertainty as moderators of the sales growth-Employment growth relationship in emerging ventures. Journal of Business Venturing, 24, 373-387.

Chang, S. J. (2003). Ownership structure, expropriation, and performance of group-affiliated companies in Korea. Academy of Management Journal, 46, 238-253.

Chang, S. J., \& Hong, J. (2000). Economic performance of group-affiliated companies in Korea: Intragroup resource sharing and internal business transactions. Academy of Management Journal, 43, 429-488.

Chemmanur, T. J., Krishnan, K., \& Nandy, D. (2011). How does venture capital financing improve efficiency in private firms? A look beneath the surface. Review of Financial Studies, 24, 4037-4090.

Chua, J., Chrisman, J., \& Sharma, P. (1999). Defining the family business by behavior. Entrepreneurship Theory and Practice, 23(4), 19-39.

Cingano, F., \& Schivardi, F. (2004). Identifying the sources of local productivity growth. Journal of the European Economic Association, 2(4), 720-742.

Colombo, M. G., \& Grilli, L. (2005). Founders' human capital and the growth of new technology-based firms: A competence-based view. Research Policy, 34(6), 795-816.

Colombo, M. G., \& Grilli, L. (2007). Funding gaps? Access to bank loans by high-tech start-ups. Small Business Economics, 29(1-2), 25-46.

Colombo, M. G., \& Grilli, L. (2013). The creation of a middlemanagement level by entrepreneurial ventures: Testing economic theories of organisational design. Journal of Economics and Management Strategy, 22(2), 390-422 .

Colombo, M. G., Grilli, L., \& Murtinu, S. (2011). R\&D subsidies and the performance of high-tech start-ups. Economics Letters, 112(1), 97-99.

Colombo, M. G., Grilli, L., Murtinu, S., Piscitello, L., \& Piva, E. (2009). Effects of international R\&D alliances on performance of high-tech start-ups: A longitudinal analysis. Strategic Entrepreneurship Journal, 3(4), 346-368.

Connelly, B. L., Hoskisson, R. E., Tihanyi, L., \& Trevis Certo, S. (2010). Ownership as a form of corporate governance. Journal of Management Studies, 47(8), 1561-1589.

Croce, A., Martí, J., \& Murtinu, S. (2012). The impact of venture capital on the productivity growth of European entrepreneurial firms: 'screening' or 'value added' effect? Journal of Business Venturing (forthcoming).

Dalziel, T., White, R. E., \& Arthurs, J. D. (2011). Principal costs in initial public offerings. Journal of Management Studies, 48(6), 1346-1364.

Delmar, F. (1997). Measuring growth: Methodological considerations and empirical results. In R. Donckels \& A. Miettinen (Eds.), Entrepreneurship and SME research: On its way to the next millennium (pp. 199-216). Hants (UK): Ashgate Publishing.

Demsetz, H., \& Villalonga, B. (2001). Ownership structure and corporate performance. Journal of Corporate Finance, 7, 209-233.

Dixon, W. J. (1960). Simplified estimation from censored normal samples. Annals of Mathematical Statistics, 31, $385-391$.
Driffield, N., Du, J., \& Girma, S. (2008). Optimal geographic diversification and firm performance: Evidence from the U.K. Journal of Productivity Analysis, 30(2), 145-154.

Eckhardt, J. T., Shane, S., \& Delmar, F. (2006). Multistage selection and the financing of new ventures. Management Science, 52(2), 220-232.

European Commission. (2011). Establishing a programme for the competitiveness of enterprises and small and medium-sized enterprises (2014-2020). Available at: http://ec.europa.eu/ cip/files/cosme/com_2011_0834_proposition_de_reglement_ en.pdf.

Faccio, M., Lang, L., \& Young, L. (2001). Dividends and expropriation. American Economic Review, 91, 54-78.

Fama, E. F., \& Jensen, M. C. (1983). Separation of ownership and control. Journal of Law and Economics, 26(2), 301-325.

Faulkender, M., \& Petersen, M. (2006). Does the source of capital affect capital structure? Review of Financial Studies, 19, 45-79.

Filatotchev, I., Wright, M., \& Arberk, M. (2006). Venture capitalists, syndication and governance in initial public offerings. Small Business Economics, 26, 337-350.

Florackis, C., \& Ozkan, A. (2009). The impact of managerial entrenchment on agency costs: An empirical investigation using UK panel data. European Financial Management, 15(3), 497-528.

Gans, J. S., \& Stern, S. (2003). The product market and the market for "ideas": Commercialization strategies for technology entrepreneurs. Research Policy, 32(2), 333-350.

Girma, S., Görg, H., \& Strobl, E. (2007). The effect of government grants on plant level productivity. Economics Letters, 94(3), 439-444.

Hall, B. H., \& Mairesse, J. (1995). Exploring the relationship between R\&D and productivity in French manufacturing firms. Journal of Econometrics, 65(1), 263-293.

Harvey, C. R., Lins, K. V., \& Roper, A. H. (2004). The effect of capital structure when expected agency costs are extreme. Journal of Financial Economics, 74, 3-30.

He, J. (2008). Do founders matter? A study of executive compensation, governance structure and firm performance. Journal of Business Venturing, 23(3), 257-279.

Hillman, A. J., \& Dalziel, T. (2003). Boards of directors and firm performance: Integrating agency and resource dependence perspectives. The Academy of Management Review, 28(3), 383-396.

Holtz-Eakin, D., Joulfian, D., \& Rosen, H. S. (1993). The Carnagie conjecture: Some empirical evidence. Quarterly Journal of Economics, 108, 413-435.

Javorcik, B. S. (2004). Does foreign direct investment increase the productivity of domestic firms? In search of spillovers through backward linkages. The American Economic Review, 94(3), 605-627.

Jensen, M. C. (1986). Agency costs of free cash flow, corporate finance, and takeovers. American Economic Review, 76, 323-329.

Kahneman, D., Slovic, P., \& Tversky, A. (1982). Judgment under uncertainty: Heuristics and biases. Cambridge: Cambridge University Press.

Kerr, W. R., Lerner, J., \& Schoar, A. (2011). The consequences of entrepreneurial finance: Evidence from angel financings. The Review of Financial Studies (forthcoming). 
Lerner, J. (1998). "Angel” financing and public policy: An overview. Journal of Banking \& Finance, 22(6-8), 773-783.

Levinsohn, J., \& Petrin, A. (2003). Estimating production functions using inputs to control for unobservables. Review of Economic Studies, 70(2), 317-342.

OECD. (2012). Financing high-growth firms: The role of angel investors. Available at: http://www.oecd.org/sti/financing

high-growthfirmstheroleofangelinvestors.htm.

Olley, G. S., \& Pakes, A. (1996). The dynamics of productivity in telecommunications equipment industry. Econometrica, 64(6), 1263-1297.

Roodman, D. (2009). A note on the theme of too many instruments. Oxford Bulletin of Economics and Statistics, 71(1), 135-158.

Schulze, W. S., Lubatkin, M. H., \& Dino, R. N. (2002). Altruism, agency, and the competitiveness of family firms. Managerial and Decision Economics, 23(4-5), 247-259.

Semykina, A., \& Wooldridge, J. M. (2010). Estimating panel data models in the presence of endogeneity and selection: Theory and application. Journal of Econometrics, 157(2), 375-380.

Shane, S. (2012). The importance of angel investing in financing the growth of entrepreneurial ventures. Quarterly

Journal of Finance, 2(2). doi:10.1142/S2010139212500097

Shleifer, A., \& Vishny, R. (1997). A survey of corporate governance. The Journal of Finance, 52(2), 737-783.

Sine, W. D., Mitsuhashi, H., \& Kirsch, D. A. (2006). Revisiting burns and stalker: Formal structure and new venture performance in emerging economic sectors. The Academy of Management Journal, 49(1), 121-132.

Singh, M., \& Davidson, W. N. (2004). Agency costs, ownership structure and corporate governance mechanisms. Journal of Banking \& Finance, 27, 793-816.

Stark, O., \& Falk, I. (1998). Transfers, empathy formation, and reverse transfers. American Economic Review, 88(2), 271-276.

Storey, D. J., \& Tether, B. S. (1998). Public policy measures to support new technology-based firms in the European Union. Research Policy, 26, 1037-1057.
Teece, D. J. (1986). Profiting from technological innovation: Implications for integration, collaboration, licensing, and public policy. Research Policy, 15, 285-305.

Van Auken, H. E. (2001). Financing small technology-based companies: The relationship between familiarity with capital and ability to price and negotiate investment. Journal of Small Business Management, 39(3), 240-258.

Van Biesebroeck, J. (2007). Robustness of productivity estimates. Journal of Industrial Economics, 55, 529-569.

Villalonga, B., \& Amit, R. (2006). How do family ownership, control and management affect firm value? Journal of Financial Economics, 80, 385-417.

Walsh, J. P., \& Seward, J. K. (1990). On the efficiency of internal and external corporate control mechanisms. The Academy of Management Review, 15(3), 421-458.

Ward, D., \& Filatotchev, I. (2010). Principal-principal-agency relationships and the role of external governance. Managerial and Decision Economics, 31(4), 249-261.

Wiklund, J., \& Shepherd, D. (2003a). Aspiring for, and achieving growth: The moderating role of resources and opportunities. Journal of Management Studies, 40(8), 1919-1941.

Wiklund, J., \& Shepherd, D. (2003b). Knowledge-based resources, entrepreneurial orientation, and the performance of small and medium-sized businesses. Strategic Management Journal, 24(13), 1307-1314.

Williamson, O. E. (1988). Corporate finance and corporate governance. Journal of Finance, 43, 567-591.

Windmeijer, F. (2005). A finite sample correction for the variance of linear efficient two-step GMM estimators. Journal of Econometrics, 126(1), 25-51.

Wooldridge, J. M. (1995). Selection corrections for panel data models under conditional mean independence assumptions. Journal of Econometrics, 68, 115-132.

Wooldridge, J. M. (2002). Econometric analysis of cross section and panel data. Cambridge: MIT Press.

Young, M. N., Peng, M. W., Ahlstrom, D., Bruton, G. D., \& Jiang, Y. (2008). Corporate governance in emerging economies: A review of the principal-principal perspective. Journal of Management Studies, 45, 196-220. 